\title{
Streamflow, Groundwater, and Water-Quality Monitoring by USGS Nevada Water Science Center
}

The U.S. Geological Survey (USGS) has monitored and assessed the quantity and quality of our Nation's streams and aquifers since its inception in 1879. Today, the USGS provides hydrologic information to aid in the evaluation of the availability and suitability of water for public and domestic supply, agriculture, aquatic ecosystems, mining, and energy development. Although the USGS has no responsibility for the regulation of water resources, the USGS hydrologic data complement much of the data collected by state, county, and municipal agencies, tribal nations, U.S. District Court Water Masters, and other federal agencies such as the Environmental Protection Agency, which focuses on monitoring for regulatory compliance. The USGS continues its mission to provide timely and relevant water-resources data and information that are available to water-resource managers, non-profit organizations, industry, academia, and the public. Data collected by the USGS provide the science needed for informed decision-making related to resource management and restoration, assessment of flood and drought hazards, ecosystem health, and effects on water resources from land-use changes.

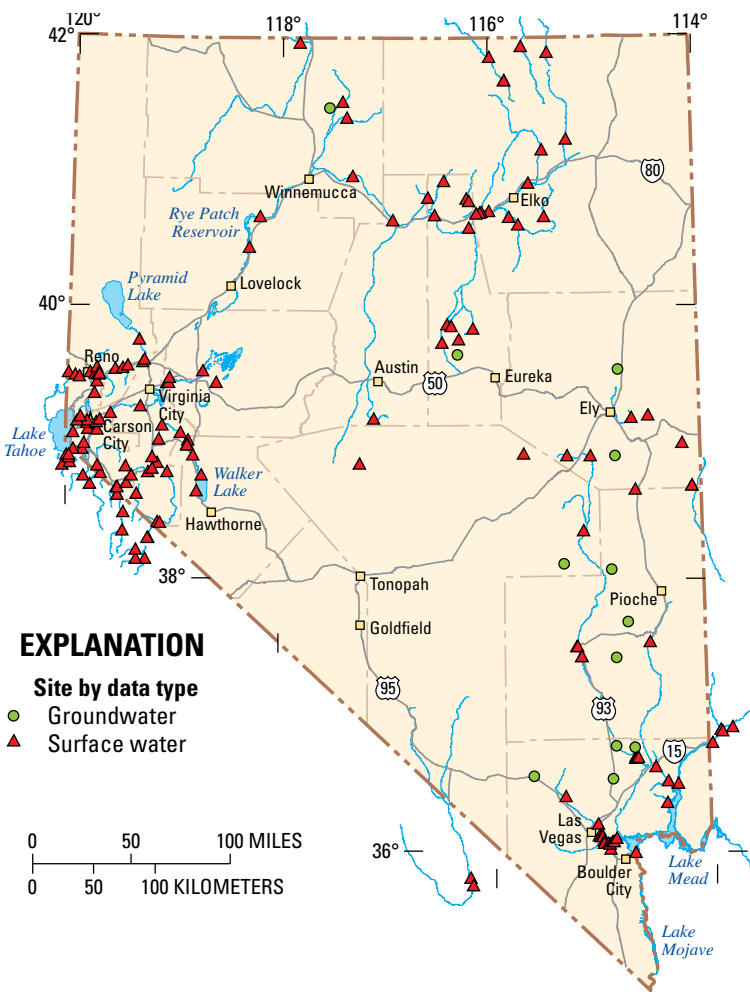

Figure 1. Continuous surface-water and groundwater monitoring sites operated by the Nevada Water Science Center.

\section{Streamflow Monitoring}

The USGS Nevada Water Science Center (WSC) currently (2012) monitors continuous streamflow at 182 locations across Nevada and surrounding states. Miscellaneous streamflow measurements are obtained at 87 sites. Peak streamflow is monitored at 31 sites in Nevada by utilizing a network of crest stage gages. Most streamflow stations are funded and operated in cooperation with other federal, state, county, or municipal agencies and tribal nations.

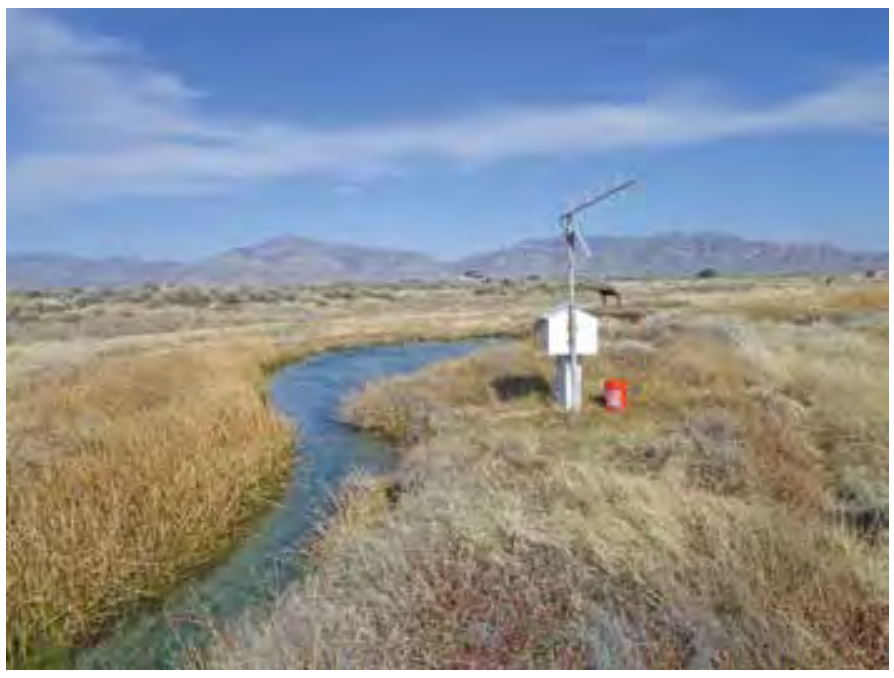

Figure 2. Streamflow station at Hot Creek near Sunnyside, Nevada.

Streamflow data are available on the Nevada WSC web page (http://nevada.usgs.gov/water/index.htm) in real time. Longterm data (greater than 5 years of continuous record) provide baseline data that can be used to analyze peak, mean, and low flows. Data can also be used to determine flood frequency.

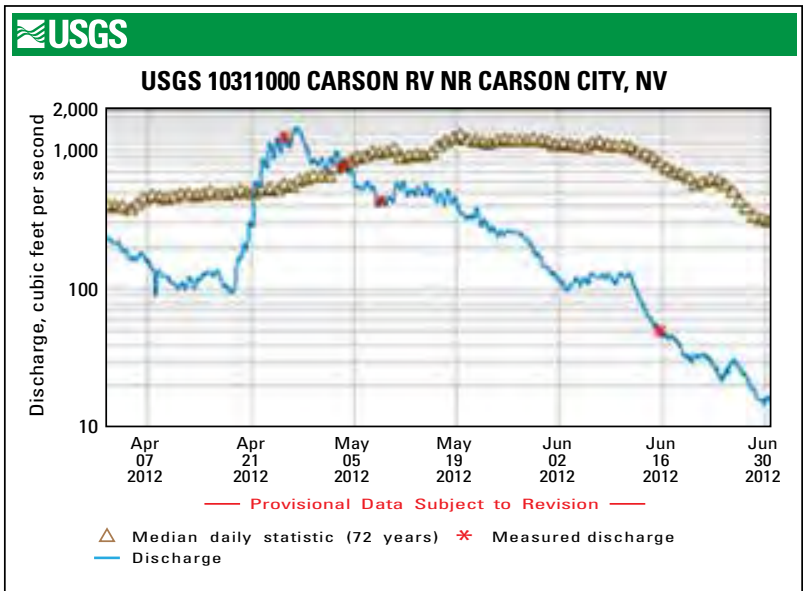

Figure 3. Real-time streamflow hydrograph and long-term daily median streamflow from the Nevada Water Science Center web page showing Carson River near Carson City, Nevada. 


\section{Groundwater Monitoring}

Monitoring of groundwater levels is used to evaluate current hydrologic conditions and determine temporal trends. Groundwater monitoring is needed by resource managers and is of interest to the public as reliance on groundwater in Nevada increases to meet public, domestic, agricultural, and industrial demands.

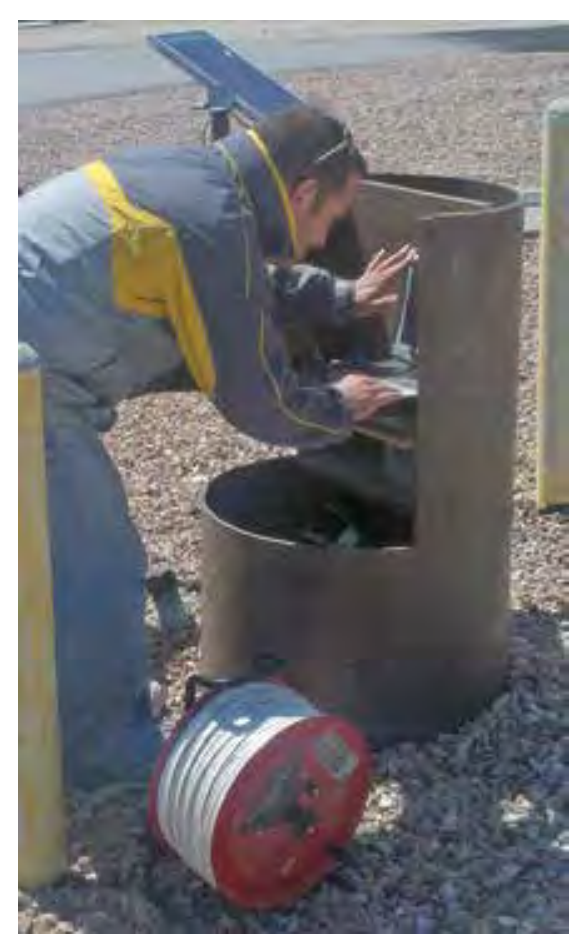

The USGS currently

(2012) monitors groundwater levels continuously in 27 wells and annually in 1,081 wells across Nevada. Groundwater data are available on the Nevada WSC web page: http://nevada. usgs.gov/water/index. htm.

Figure 4. U.S. Geological Survey hydrographer collecting data at a continuous groundwater monitoring well.

\section{Water-Quality Monitoring}

Water-quality monitoring helps to ensure that water resources continue to support designated uses, and provides a mechanism to monitor the effectiveness of infrastructure and restoration measures throughout our Nation's waterways and aquifers. Information gained from water-quality monitoring can help to protect the public and aquatic ecosystems from potential effects of poor quality water, identify emerging water-quality issues, and delineate the geographic areas in which to concentrate data-collection efforts, thus helping to ensure cost-effective water management.

USGS currently (2012) monitors water quality continuously at 10 stream sites in Nevada, and discrete samples are collected at 177 locations. Water-quality data are used to assess current conditions and temporal trends. Water-quality constituent concentrations, and nutrient and sediment loads, typically show significant changes during stormflow, which can require intense sampling during such events. These data are useful in identifying potential water-quality impairment.

Operation of a continuous water-quality monitoring station provides a nearly continuous record of water-quality changes with time. Data from the sensors are used as surrogates to provide estimates of chemical concentrations. Water-quality data are available on the Nevada WSC web page: http://nevada.usgs.gov/water/ index.htm.

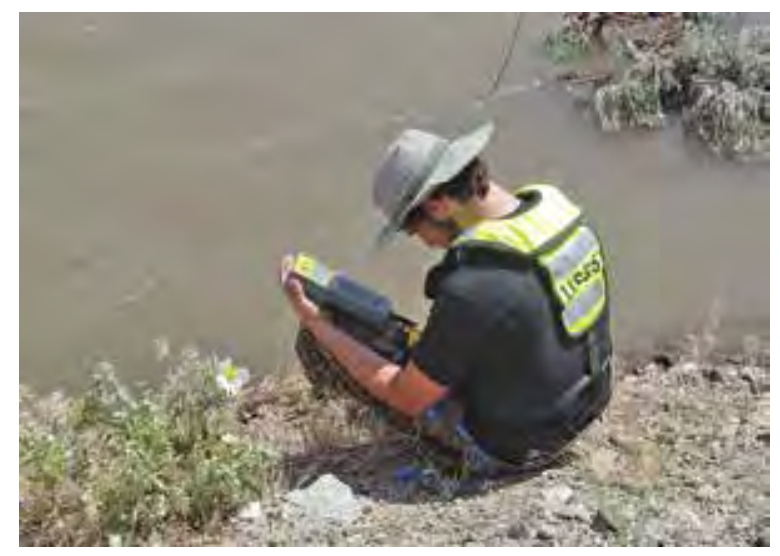

Figure 5. U.S. Geological Survey hydrographer collecting water-quality data.

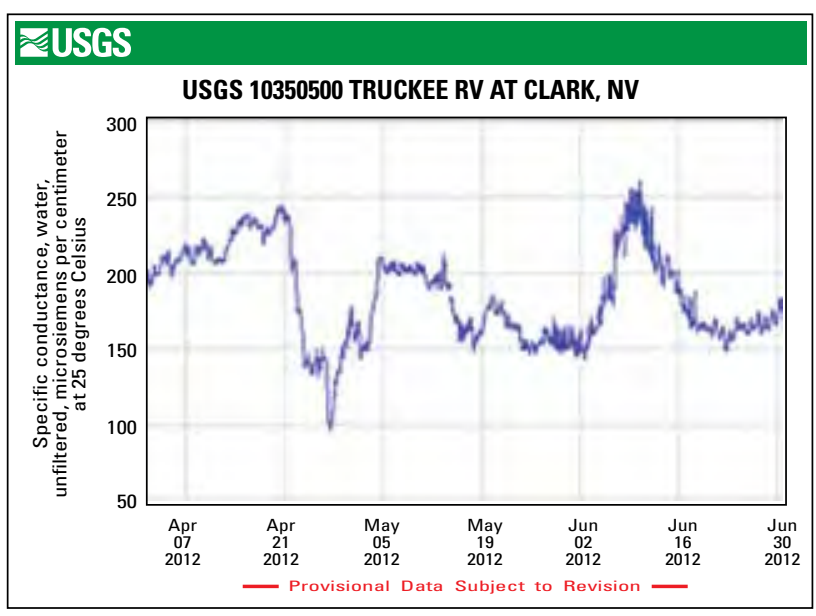

Figure 6. Time-series plot from the Nevada Water Science Center web page showing specific-conductance values during late spring at Truckee River at Clark, Nevada.

\section{Source for USGS Hydrologic Data and Reports for Nevada}

Visit http://nevada.usgs.gov/water/index.htm for access to online data and reports, including the following:

- Streamflow and rainfall data

- Water-quality and groundwater data

- NWIS web (National Water Information System) for realtime and historical water data, and

- Online reports

For additional information, please contact the Data Chief at (775) 887-7693 or by email at snberris@usgs.gov.

Marsha L. Gipson, Kurtiss Schmidt

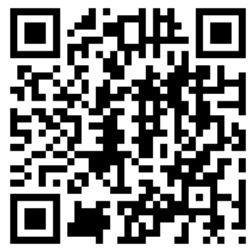

